\title{
PENGARUH KONSELING TERHADAP TINGKAT KECEMASAN AKSEPTOR KB IUD POST PLASENTA DI RSUD KOTA MADIUN TAHUN 2019
}

\section{THE INFLUENCE OF COUNSELING ON THE ANXIETY LEVEL OF IUD POST PLASENTA CONTRACEPTION PARTICIPANT In MADIUN HOSPITAL}

\author{
2019 \\ Halimatus Saidah ${ }^{1}$, Dewi Kartika Sari² \\ Fakultas Ilmu Kesehatan Universitas Kadiri \\ Jl. Selomangkleng No.1 Kediri Jawa Timur \\ Telp. (0354) 771649 \\ e-mail: halimatus.saidah@unik-kediri.ac.id
}

\begin{tabular}{c} 
Abstrak \\
\hline
\end{tabular}

Adanya teknik baru yaitu IUD Post Plasenta maka dapat memberikan harapan dan kesempatan bagi ibu yang tidak ingin hamil lagi namun juga dapat meningkatkan kecemasan dalam penggunaan awal. Beberapa faktor yang mempengaruhi kecemasan adalah: usia, keadaan fisik, sosial budaya, pendidikan dan pengetahuan. Tujuan penelitian ini adalah Pengaruh Konseling Terhadap Tingkat Kecemasan Akseptor KB IUD Post Plasenta di RSUD Kota Madiun 2019

Desain penelitian yang digunakan adalah penelitian korelasional. Populasi yang diteliti adalah semua akseptor KB IUD Post Plasenta di RSUD Kota Madiun, dengan jumlah 37 orang, pada bulan Maret 2019 dengan teknik accidental sampling diperoleh sampel 37 orang. Instrumen dalam penelitian inimenggunakan kuesioner. Hasil penelitian kemudian dianalisa dengan menggunakan $T$ Test pada tarag signifikasi 0,05.

Hasil penelitian yang dilakukan menunjukan Tingkat kecemasan akseptor KB IUD Post Plasenta pada akseptor KB IUD Post Plasenta sebelum diberikan konseling, hampir seluruhnya 30 responden $(81,1 \%)$ dengan tidak ada kecemasan. Tingkat kecemasan akseptor KB IUD Post Plasenta pada akseptor KB IUD Post Plasenta sesudah diberikan konseling, hampir seluruhnya 33 responden $(89,2 \%)$ dengan tidak ada kecemasan. Ada Pengaruh Konseling Terhadap Tingkat Kecemasan Akseptor KB IUD Post Plasenta di RSUD Kota Madiun 2019, dengan $p$ value $0,000<0,05$.

Hasil analisis menunjukan Ada Pengaruh Konseling Terhadap Tingkat Kecemasan Akseptor KB IUD Post Plasenta di RSUD Kota Madiun 2019. Berdasarkan hasil penelitian diharapkan tenaga kesehatan dapat mengetahui pentingnya memberikan pengetahuan pada ibu calon akseptor IUD Post Plasenta, sehingga diharapkan dapat mencegah terjadinya tingkat kecemasan pada akseptor IUD Post Plasenta

Kata Kunci : Konseling, Tingkat Kecemasan, KB IUD Post Plasenta, Akseptor KB 


\section{ABSTRACT}

Background. The existence of a new technique, the IUD Post Placenta, can provide hope and opportunities for mothers who do not want to get pregnant again but can also increase anxiety in early use. Some of the factors that influence anxiety are: age, physical state, social culture, education and knowledge. The purpose of this study was the Effect of Counseling on the Anxiety Level of KB Placid acceptors in the Post Regional Hospital Madiun 2019

The research design used is correlational research. The population studied was all Post Placenta IUD KB acceptors in Madiun City Hospital, with a total of 37 people, in March 2019 with an accidental sampling technique a sample of 37 people was obtained. The instrument in this study used a questionnaire. The results of the study were then analyzed using the $T$ Test at the 0.05 significance tag.

The results of the study showed that the anxiety level of the Post Placenta IUD KB acceptor on the Post Placenta IUD KB acceptor was given prior to counseling, almost all 30 respondents $(81.1 \%)$ with no anxiety. The level of anxiety of the Post Placenta IUD KB acceptor on the Post Placenta IUD KB acceptor after being given counseling, almost all 33 respondents (89.2\%) with no anxiety. There is the influence of counseling on the anxiety level of KB acceptors in the post placenta IUD in Madiun City Hospital 2019, with a $p$ value of 0,000 $<0.05$.

The analysis showed that there was an influence of counseling on the level of anxiety of KB acceptors in post placenta IUD in Madiun City Hospital 2019. Based on the results of the study, it was expected that health workers could know the importance of giving knowledge to mothers of post placenta IUD acceptors, so that they were expected to be able to prevent anxiety levels in the Post Placenta IUD acceptor.

Elder Keywords : Counseling, Anxiety Level, IUD Post Placenta, Acceptor 


\section{PENDAHULUAN}

Penggunaan alat kontrasepsi IUD (Intra Uterine Device) pada akseptor KB baru yang dipasang pasca persalinan.AKDR atau IUD atau spiral adalah suatu benda kecil yang terbuat dari plastik yang lentur, mempunyai lilitan tembaga atau juga mengandung hormon dan dimasukkan kedalam rahim melalui vagina dan mempunyai benang (Handayani, 2010).Dengan adanya teknik baru yaitu IUD Post Plasenta maka dapat memberikan harapan dan kesempatan bagi ibu yang tidak ingin hamil lagi.Di Indonesia dengan kesulitan hidup yang cukup tinggi (30\% miskin) dan banyaknya Unmet Need Pregnancy (8,6\%) maka teknologi ini perlu untuk ditawarkan kepada pasien post partum dengan cara memberikan konseling sebelum persalinan. Peningkatan penggunaan IUD Post Plasentaakan dapat mengurangi jumlah kehamilan yang tidak diinginkan dimasa depan, sehingga akan mengurangi angka kematian ibu dan bayi di Indonesia.

Berdasarkan data Nasional didapatkan bahwa pemakaian alat kontrasepsi pasca persalinan dan pasca keguguran secara nasional pada Bulan Agustus tahun 2017 yaitu 112.613 akseptor KB memilih IUD (15.15\%), 25.481 peserta MOW $(3.43 \%), 10457$ peserta implant $(9,48 \%), 379,866$ peserta suntikan $(51.10 \%), 131.862$ peserta pil $(17,74 \%), 556$ peserta MOP (0.07\%) dan 22.522 peserta kondom (3.03\%). (BKKBN, 2016)Di Jawa Timur pada Bulan Agustus tahun 2015 di dapatkan jumlah pemakai kontrasepsi IUD sebanyak 19.269 akseptor (16.8\%) dari total keseluruhan pemakai kontrsepsi KB sejumlah 743.358 akseptor (BKKBN, 2015). Data dari tingkat Kabupaten Madiun pada tahun 2013 didapat jumlah pemakai alat kontrasepsi IUD sebanyak 58.231 akseptor (40\%) dari total keseluruhan pemerintah, swasta, maupun masyarakat sendiri. Salah satunya dengan mensosialisasikan metode kontrasepsi terkini IUD Post Placenta oleh pemakai alat kontrasepsi KB sejumlah 143.205 akseptor (BKKBN Kabupaten Madiun, 2015). Pemakaina KB IUD di RSUD Kota Madiun 2015 didapat jumlah akseptor IUD sebanyak 703 dan akseptor MOW 420. Sedangkan pada bulan Desember 2016 didapatkan jumlah pemakai alat kontrasepsi IUD 36 diantaranya dengan pemasangan IUD Post Plasenta dan pemakai alat kontrasepsi MOW 12 orang.

Berdasarkan hasil studi pendahuluan yang telah dilakukan Bulan Januari 2019 di RSUD Madiun dengan wawancara pada 10 akseptor KB IUD Post Plasenta didapatkan $7 \quad(70 \%)$ ibu yang menggunakan KB IUD Post Plasenta mengatakan cemas dengan dirinya setelah dilakukan pemasangan IUD Post Plasenta dengan alasan takut karena kurangnya pemahaman mereka tentang pemasangan dan 3 (30\%) ibu mengatakan tidak cemas setelah pemasangan IUD Post Plasenta dengan alasan ibu pernah mendapatkan informasi tentang penggunaan KB IUD Post Plasenta. Dari latar belakang tersebut dapat ditarik kesimpulan ibu yang cemas pasca pemasangan IUD Post Plasenta disebabkan kurangnya pemahaman mereka tentang IUDPost Plasenta/ pasca salin.

Menurut Carpenito (2001),beberapa faktor yang mempengaruhi kecemasan adalah: usia, keadaan fisik, sosial budaya, pendidikan dan pengetahuan. Efek samping yang terdapat pada IUD Post Plasenta, memang cukup banyak seperti ekspulsi, infeksi, perforasi, Hal inilah yang membuat ibu merasa takut dan merasa cemas, dengan adanya cemas yang dirasakan oleh ibu ini bisa berdampak pada psikologis ibu (Irianto, 2012).

Gerakan Keluarga Berencana (KB) sebagai salah satu kegiatan pokok pembangunan keluarga sejahtera telah di lakukan baik oleh BKKBN.Metode IUD Post Placenta mempunyai keuntungan tersendiri, selain pemasanganya lebih efektif karena dilakukan setelah plasenta lahir 
sekaligus mengurangi angka kesakitan Ibu.Pada hasil expert meeting tahun 2009 dikatakan bahwa penggunaan IUD post placenta dan postabortus perlu terus digalakkan karena sangat efektif, mengingat angkakelahiran rata-rata 4.000 .000 per tahun (Handayani, 2010).

Dampak dari rasa cemas ibu ini mengakibatkan terganggunya kebutuhan istirahat tidur, takut untuk mobilisasi, serta nafsu makan menurun akan tetapi dampak bila tidak memakai KB IUD perempuan setiap tahun terdapat 500.000 perempuan meninggal karena berbagai masalah yang melingkupi kehamilan, persalinan, dan pengguguran kandungan (aborsi) yang tidak aman. Resiko hamil lagi dengan jarak yang cepat hal ini menuntut banyak energi dan kekuatan tubuh perempuan.Kalau belum pulih dari satu persalinan dan sudah hamil lagi, maka tubuhnya tidak sempat memulihkan kebugaran.Berbagai masalah, bahkan bahaya kematian, bisa menghadang (Maulana, 2009).

\section{Metode}

Penelitian ini merupakan penelitian Pre Eksperimental On Group Pre TestPost TestDesign dengan pendekatan Cross Sectional. Populasi pada penelitian ini adalah semua akseptor KB IUD Post Plasenta di RSUD Kota Madiun, dengan jumlah 37 orang, pada bulan Maret 2019. Sampel diambil dengan menggunakan total populasi yaitu semua akseptor KB IUD Post Plasenta di RSUD Kota Madiun, dengan jumlah 37 orang, pada bulan Maret 2019.

Variabel independen pada penelitian ini adalah Konseling dan variabel dependen yaitu tingkat kecemasan akseptor KB IUD Post Plasenta. Instrument penelitian menggunakan kuesioner dengan tingkat kecemasan akseptor IUD Post Plasenta diambil dengan menggunakan SkalaHRSA (Hamilton RatingScale For Anxity). Penelitian dilakukan pada bulan Maret tahun 2019,
Solusi yang dapat dilakukan pada akseptor KB IUD Post Plasenta yang mengalami tingkat kecemasan adalah dengan memberikan konseling tentang pasca pemasangan IUD Post Plasenta. Hal ini petugas kesehatan harus memberikan komunikasi, informasi, edukasi (KIE) untuk meningkatkan pengetahuan bagi akseptor KB yang baru cara pemasangan. Tentang kunjungan ulang, efek samping dan penanganan AKDR, untuk kunjungan ulangnya yaitu: pertama, 1 bulan pasca pemasangan, 3 bulan selanjutnya, setiap 6 bulan berikutnya, 1 tahun sekali, akan tetapi ibu harus segera datang ke petugas kesehatan bila terjadi perdarahan banyak terasa kram pada abdomen, kejang (Handayani, 2011). Berdasarkan latar belakang masalah di atas maka penulis tertarik untuk melakukan penelitian tentang Pengaruh Konseling Terhadap Tingkat Kecemasan Akseptor KB IUD Post Plasenta di RSUD Kota Madiun 2019.

kemudian data dianalisis dengan menggunakan uji $T$ test dengan kriteria dalam pengambilan keputusan uji statistik 
dengan $\alpha$ : 0,05 jika dari hasil uji statisti didapatkan Q_Value < 0,05 maka H0 ditolak, H1 diterima dan jika Q_value > 0,05 maka H0 diterima, $\mathrm{H} 1$ ditolak.

\section{HASIL DAN PEMBAHASAN}

Dari hasil pengumpulan data, maka diperoleh:

a. Data Umum

1) Umur

Tabel 1.Distribusi Umur

\begin{tabular}{llll}
\hline No & Umur & Frekuensi & $\%$ \\
\hline 1 & $\begin{array}{l}<20 \\
\text { Tahun }\end{array}$ & 0 & 0 \\
\hline 2 & $\begin{array}{l}20-35 \\
\text { Tahun }\end{array}$ & 32 & 86,5 \\
& $>35$ & 5 & 13,5 \\
\hline 3 & tahun & & \\
\hline Jumlah & 37 & 100
\end{tabular}

Tabel 1 menunjukkan bahwa dari 37 responden yang diteliti hampir seluruhnya 32 responden $(86,5 \%)$ usia $20-35$ tahun dan sebagian kecil 5 responden (13,5\%) usia $>35$ tahun.

Pendidikan

Tabel 2 Distribusi Pendidikan

\begin{tabular}{llll}
\hline No & Pendidikan & Frekuensi & $\%$ \\
\hline 1 & Dasar & 0 & 0 \\
\hline 2 & Menengah & 32 & 86,5 \\
\hline 3 & Tinggi & 5 & 13,5 \\
\hline Jumlah & & 37 & 100 \\
\hline
\end{tabular}

Tabel 2 menunjukan bahwa dari 37 reponden yang diteliti hampir seluruhnya 32 responden $(86,5 \%)$ dengan pendidikan menengah dan 5 responden $(13,5 \%)$ dengan pendidikan tinggi (PT) Pekerjaan

Tabel 3 Distribusi Pekerjaan

\begin{tabular}{llll}
\hline No & Pekerjaan & Frekuensi & $\%$ \\
\hline 1 & Bekerja & 5 & 13,5 \\
\hline 2 & Tidak Bekerja & 32 & 86,5 \\
\hline Jumlah & & 37 & 100 \\
\hline
\end{tabular}

Tabel 3 menunjukkan bahwa dari 37 responden yang diteliti hampir seluruhnya 32 responden $(86,5 \%)$ tidak bekerja, dan sebagian kecil 5 responden $(13,5 \%)$ bekerja.

Paritas/jumlah anak

Tabel 4 Distribusi Jumlah Anak

Tabel 4 menunjukkan bahwa dari 37 responden yang diteliti sebagian besar 22 responden $(59,5 \%)$ dengan paritas primipara, hampir

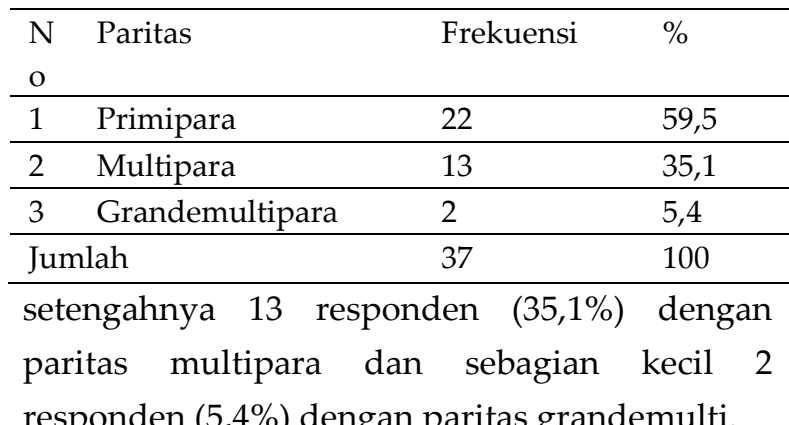

\section{Data Khusus}

Tingkat kecemasan akseptor KB IUD Post Plasenta pada akseptor KBPost Plasenta sebelum diberikan konseling

Tabel 5 Distribusi Tingkat Kecemasan Akseptor KB IUD Post Plasenta sebelum diberikan Konseling

\begin{tabular}{|c|c|c|c|c|}
\hline No & $\begin{array}{l}\text { Tingkat Kecemasan } \\
\text { Diberikan Konseling }\end{array}$ & Sebelum & $\mathrm{F}$ & $\%$ \\
\hline 1 & Tidak Ada Kecemasan & & 22 & 59,5 \\
\hline 2 & Kecemasan Ringan & & 13 & 35,1 \\
\hline 3 & Kecemasan Sedang & & 2 & 5,4 \\
\hline 4 & Kecemasan Berat & & 0 & 0 \\
\hline \multicolumn{2}{|c|}{ Jumlah } & & 37 & 100 \\
\hline
\end{tabular}

Tabel 5 menunjukkan bahwa dari 37 responden yang diteliti hampir seluruhnya 30 responden $(81,1 \%)$ dengan tidak ada kecemasan, sebagian kecil 2 responden (13,5\%) dengan kecemasan ringan dan 5 responden $(13,5 \%)$ dengan kecemasan sedang.

Tingkat kecemasan akseptor KB IUD Post Plasenta pada akseptor KBPost Plasenta sesudah diberikan konseling 


\section{Tabel 6}

Distribusi Tingkat Kecemasan Akseptor KB IUD Post Plasenta Sesudah dan sebelum diberikan Konseling.

\begin{tabular}{clcc}
\hline No & Tingkat Kecemasan Diberikan Konseling & F & $\%$ \\
\hline 1 & Tidak Ada Kecemasan & 33 & 89,2 \\
\hline 2 & Kecemasan Ringan & 4 & 10,8 \\
\hline 3 & Kecemasan Sedang & 0 & 5,4 \\
\hline 4 & Kecemasan Berat & 0 & 0 \\
\hline Jumlah & 37 & 100 \\
\hline
\end{tabular}

Tabel 6 menunjukkan bahwa dari 37 responden yang diteliti hampir seluruhnya 33 responden $(89,2 \%)$ dengan tidak ada kecemasan dan sebagian kecil 4 responden $(10,8 \%)$ dengan kecemasan ringan.

Pengaruh Konseling terhadap tingkat kecemasan akseptor KB IUD Post Plasenta pada akseptor KB Post Plasenta

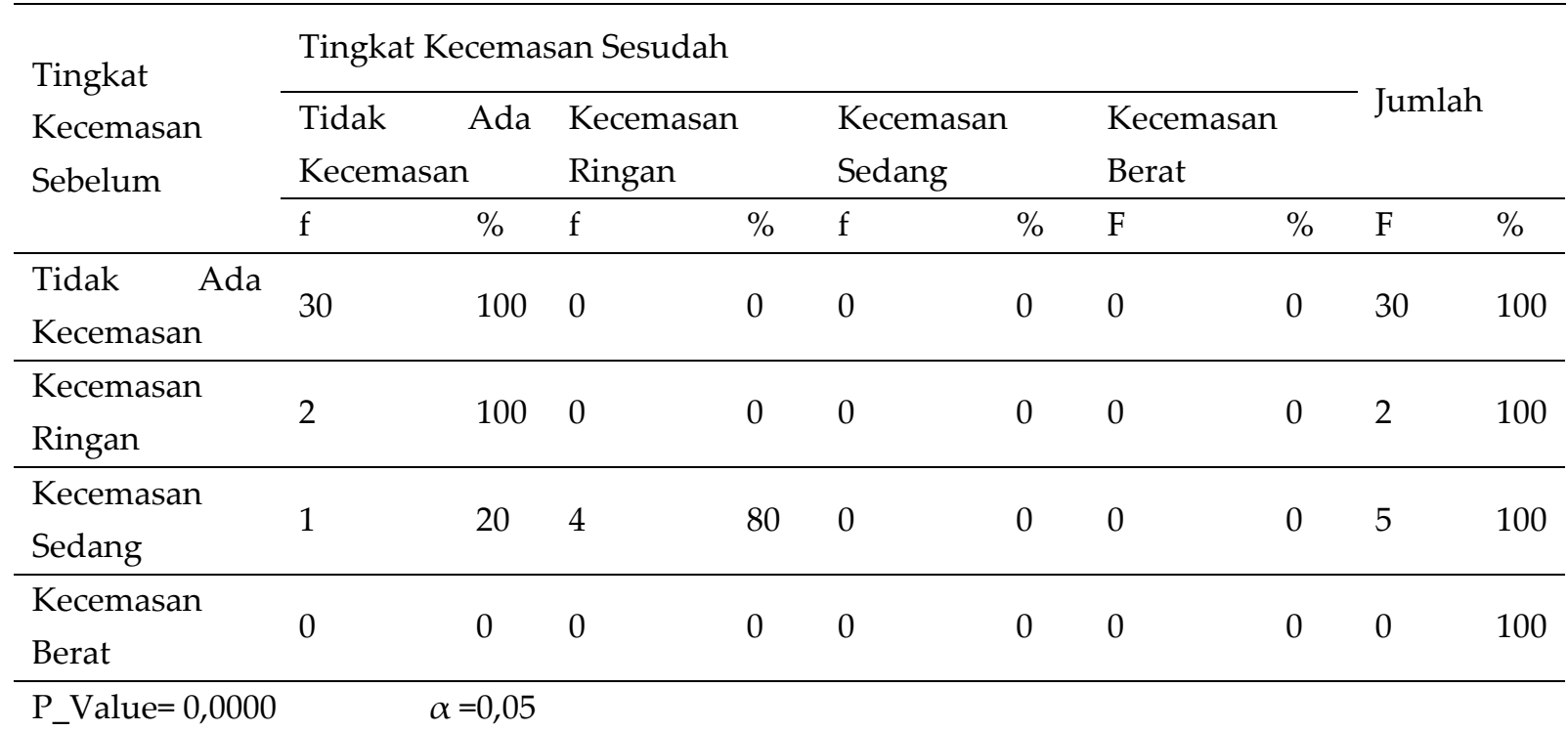

Tabel 7 Pengaruh Konseling Terhadap Tingkat Kecemasan Akseptor KB IUD Post Plasenta Dari tabel 7 tersebut dapat diketahui bahwa dari 37 responden tyang ditelitisebelum diberikan konseling dengan tidak ada kecemasan dan sesudah diberikan konseling tidak ada kecemasan 30 responden (100\%).Sebelum diberikan konseling dengan kecemasan ringan dan sesudah diberikan konseling tidak ada kecemasan 2 responden (100\%).Sebelum diberikan konseling dengan kecemasan sedang dan sesudah diberikan konseling tidak ada kecemasan 1 responden $(20 \%)$, sebelum diberikan konseling dengan kecemasan sedang dan sesudah diberikan konseling kecemasan ringan 4 responden $(80 \%)$. Berdasarkan hasil perhitungan dengan menggunakan uji $T$ TestdidapatkanP-Value $=0,0000, \alpha=0,05$ (P-Value $=0,0000<\alpha=0,05$ )

\section{Diskusi}

Berdasarkan hasil penelitian tentang tingkat kecemasan akseptor KB IUD Post
Plasenta sebelum diberikan konseling di dapatkan bahwa dari 37 responden yang diteliti 
hampir seluruhnya 30 responden $(81,1 \%)$ dengan tidak ada kecemasan, sebagian kecil 2 responden $(5,4 \%)$ dengan kecemasan ringan dan 5 responden $(13,5 \%)$ dengan kecemasan sedang. Hal tersebut disebabkan oleh hampir seluruhnya 32 responden (86,5\%) usia 20-35 tahun dan sebagian kecil 5 responden (13,5\%) usia >35 tahun, sehingga dengan usia yang relatif muda akan memiliki tingkat kecemasan yang lebih tinggi di bandingakan dengan usia yang sudah matang.Sesuai dengan pendapat Carpenito (2002) ,beberapa faktor yang mempengaruhi kecemasan adalah umur. Umur yang lebih muda lebih mudah menderita stress dari pada umur yang lebih tua, karena selain itu umur yang masih relatif muda memiliki pengetahuan dan pengalaman yang belum begitu banyak tentang IUD pasca salin. Ketidaktahuan terhadap suatu hal dianggap sebagai tekanan yang dapat menimbulkan kecemasan. Stress dan kecemasan dapat terjadi pada individu dengantingkat pengetahuan yang rendah, disebabkan karena kurangnya informasi yang diperoleh.

Berdasarkan hasil penelitian didapatkan hampir seluruhnya 30 responden $(81,1 \%)$ dengan tidak ada kecemasan . Tingkat kecemasan rendah dan sedang memungkinkan disebabkan oleh faktor usia, sehingga dengan usia yang relatif muda membutuhkan banyak informasi tentang IUD Post Plasenta untuk mengurangi tingkat kecemasan IUD Post Plasenta sebelum pemasangan. Konseling merupakan usaha untuk menimbulkan perubahan tingkah laku secara sukarela pada diri klien (klien ingin mengubah tingkah lakunya dan meminta bantuan kepada konselor).

Beradasarkan hasil penelitian tentang Tingkat kecemasan akseptor KB IUD Post Plasenta setelah diberikan konseling didapatkan bahwa dari 37 responden yang diteliti hampir seluruhnya 33 responden $(89,2 \%)$ dengan tidak ada kecemasan dan sebagian kecil 4 responden $(10,8 \%)$ dengan kecemasan ringan. Hal tersebut disebabkan oleh faktor pendidikan hampir seluruhnya 32 responden $(86,5 \%)$ dengan pendidikan menengah dan 5 responden $(13,5 \%)$ dengan pendidikan tinggi. Sehingga dengan pendidikan yang tinggi akan memungkinkan seseorang mudah dalam menyerap informasi yang diberikan.

Sesuai dengan pendapat Carpenito (2001) ,beberapa faktor yang mempengaruhi kecemasan adalah pendidikan. Tingkat pendidikan seseorang berpengaruh dalam memberikan respon terhadap sesuatu yangdatang baik dari dalam maupun dari luar. Orang yang akan mempunyai pendidikan tinggi akan memberikan respon yang lebih rasional dibandingkan mereka yang berpendidikan rendah atau mereka yang tidak berpendidikan. Kecemasan adalah yang dapat dipelajari.Dengan demikian pendidikan yang rendah menjadi faktor penunjang terjadinya kecemasan.

Berdasarkan hasil penelitian didapatkan hampir seluruhnya 33 responden $(89,2 \%)$ dengan tidak ada kecemasan. Tingkat kecemasan setelah diberikan konseling memungkinkan dipengaruhi oleh faktor pendidikan, sehingga dengan pendidikan yang tinggi akan memudahkan seseorang dalam menyerap informasi yang diberikan tentang IUD Post Plasenta untuk mengurangi tingkat kecemasan IUD Post Plasenta sebelum pemasangan

Dari 37 responden yang diteliti pada sebelum diberikan konseling dengan tidak ada kecemasan dan sesudah diberikan konseling tidak ada kecemasan 30 responden (100\%).Sebelum diberikan konseling dengan kecemasan ringan dan sesudah diberikan konseling tidak ada kecemasan 2 responden $(100 \%)$.Sebelum diberikan konseling dengan kecemasan sedang dan sesudah diberikan konseling tidak ada kecemasan 1 responden $(20 \%)$, sebelum diberikan konseling dengan kecemasan sedang dan sesudah diberikan konseling kecemasan ringan 4 responden $(80 \%)$.

Berdasarkan hasil perhitungan uji statistik dengan menggunakan ujiT Test menunjukkan bahwa ada Pengaruh Konseling Terhadap Tingkat Kecemasan KB IUD Post Plasenta Pada Akseptor KB IUD Post Plasenta di 
RSUD Kota Madiun Tahun 2019, dengan $p$ value $0,000<0,05$.

Sesuai dengan penelitian yang telah dilakukan oleh Kusumaning (2009), hasil analisis didapatkan nilai signifikan yang diolah dengan uji statistik koefisien korelasi Rank Spearmen dengan menggunakan program SPSS for window 11.0, sehingga diperoleh @ hitung < @ table ( $\varrho$ hitung $=0,042<\varrho$ table $=0,306)$ pada taraf signifikan 0,05. Hal ini menunjukkan bahwa Pengaruh Konseling Terhadap Tingkat Kecemasan Akseptor KB IUD Post Plasenta di Gendongtataan Jakarta Selatan.

Kecemasan adalah kekhawatiran yang tidak jelas dan menyebar, yang berkaitan dengan perasan tidak pasti dan tidak berdaya (Stuart, 2006). Beberapa faktor yang mempengaruhi kecemasan adalah: usia, keadaan fisik, sosial budaya, pendidikan dan pengetahuan. Efek samping yang terdapat pada IUD, memang cukup banyak seperti ekspulsi, infeksi, perforasi, Hal inilah yang membuat ibu merasa takut dan merasa cemas,dengan adanya cemas yang dirasakan oleh ibu ini bisa berdampak pada psikologis ibu (Irianto, 2012).

\section{Simpulan}

Berdasarkan hasil penelitian didapatkan ada Pengaruh Konseling Terhadap Tingkat Kecemasan Akseptor KB IUD Post Plasenta di RSUD Kota Madiun Tahun 2019. Diharapkan petugas kesehatan harus memberikan komunikasi, informasi, edukasi (KIE) untuk meningkatkan pengetahuan bagi akseptor KB yang baru cara pemasangan. Tentang kunjungan ulang, efek samping dan penanganan AKDR, untuk kunjungan ulangnya yaitu: pertama, 1 bulan pasca pemasangan, 3 bulan selanjutnya, setiap 6 bulan berikutnya, 1 tahun sekali, akan tetapi ibu harus segera datang ke petugas kesehatan bila terjadi perdarahan banyak terasa kram pada abdomen, kejang dll.

\section{Daftar Pustaka}

Alimul H. 2010. Riset Keperawatan Dan Teknik Penulisan Ilmiah.Jakarta. Salemba Medika

Carpenito, L. 2002. Diagnosa Keperawatan Edisi 6. EGC, Jakarta

Gunarsa S, 2002. Psikologi Perawatan. BPK-GM, Jakarta.

Handayani. 2010. Buku Ajar Pelayanan Keluarga Berencana. Jakarta: Pustaka

Rihama

Hartanto, H. 2010. Keluarga Berencana Dan Kontrasepsi. Jakarta. pustaka sinar harapan

Hidayat.2010. Metode Penelitian Kebidanan dan Analisis Data. Jakarta: Salemba Medika.

Koes, I. 2012. Keluarga Berencana Untuk Para Medis $\because$ Nonmedis. Bandung.

YRAMA WIDYA

Manuaba. 2002. Ilmu Kebidanan, Penyakit Kandungan, Dan KB. Jakarta. penerbit buku kedokteran

Mirza,M. 2009. Tanya-Jawab Lengkap Dan Praktis Seputar Reproduksi,Kehamilan, Dan Merawat Anak. Jogjakarta. Tunas publising

Notoatmodjo, S. 2003. Ilmu Kesehatan Masyarakat. Jakarta: Adi Mahasatya . 2005. Metodologi Penelitian Kesehatan. Jakarta: Rineka Cipta. . 2007. Kesehatan Masyarakat Ilmu Dan Seni. Jakarta: Rineka Cipta.

Nursalam.2003. Konsep\&Penerapan Metodologi Penelitian Ilmu Keperawatan.

Jakarta: Salemba Medika

Saifuddin, SpOG(k), MPH .2010. Buku Panduan Praktis Pelayanan Kontrasepsi. Jakarta. Bina Pustaka Sarwono Prawirohardjo.

Stuart, G. 2006.Buku Saku Keperawatan Jiwa.Jakarta:EGC.

Sugiyono. 2000. Metode Penelitian Bisnis. Bandung: CV.Alfabeta 
